\title{
Review of the Mobile Stroke Unit Experience Worldwide
}

\author{
Victoria J. Calderon ${ }^{a}$ Brittany M. Kasturiarachib Eugene Lin ${ }^{a}$ \\ Vibhav Bansal $^{c}$ Osama O. Zaidat ${ }^{a}$ \\ ${ }^{a}$ Mercy Health-St. Vincent Medical Center, Toledo, $\mathrm{OH}, \mathrm{USA} ;{ }^{b}$ Ohio University Heritage \\ College of Osteopathic Medicine, Athens, $\mathrm{OH}$, USA; ' Mercy Health-St. Rita Medical Center, \\ Lima, OH, USA
}

\section{Keywords}

Emergency medical services · Mobile stroke unit · Prehospital stroke treatment · Stroke management $\cdot$ Thrombolysis

\begin{abstract}
Background: The treatment of stroke is dependent on a narrow therapeutic time window that requires interventions to be emergently pursued. Despite recent "FAST" initiatives that have underscored "time is brain," many patients still fail to present within the narrow time window to receive maximum treatment benefit from advanced stroke therapies, including recombinant tissue plasminogen activator (tPA) and mechanical thrombectomy. The convergence of emergency medical services, telemedicine, and mobile technology, including transportable computed tomography scanners, has presented a unique opportunity to advance patient stroke care in the prehospital field by shortening time to hyperacute stroke treatment with a mobile stroke unit (MSU). Summary: In this review, we provide a look at the evolution of the MSU into its current status as well as future directions. Our summary statement includes historical and implementation information, economic cost, and published clinical outcome and time metrics, including the utilization rate of thrombolysis. Key Messages: Initially hypothesized in 2003, the first MSUs were launched in Germany and adopted worldwide in acute, prehospital stroke management. These specialized ambulances have made the diagnosis and
\end{abstract}

V.J. Calderon and B.M. Kasturiarachi contributed equally to this work. 
treatment of many neurological emergencies, in addition to ischemic and hemorrhagic stroke, possible at the emergency site. Providing treatment as early as possible, including within the prehospital phase of stroke management, improves patient outcomes. As MSUs continue to collect data and improve their methods, shortened time metrics are expected, resulting in more patients who will benefit from faster treatment of their acute neurological emergencies in the prehospital field.

(C) 2018 S. Karger AG, Basel

\section{Introduction}

Stroke is the second leading cause of death worldwide since 2010, accounting for more than $11 \%$ of total mortality [1]. In the United States, stroke is the fifth leading cause of death and a major cause of long-term disability [1]. Treatment of stroke is dependent on a narrow therapeutic time window, as human nerve tissue is rapidly and irreversibly lost over time [2]. Early identification of acute ischemic stroke is vital in order to provide timely treatment through thrombolysis, which can improve clinical outcome and reduce resulting complications [2]. The only systemic, acute treatment for stroke that has been proven effective is recombinant tissue plasminogen activator (tPA), but its recommended window of use is within 3-4.5 h from stroke symptom onset $[3,4]$. The efficacy of intravenous (IV) thrombolysis is a function of time; the earlier a patient is treated, the greater the likelihood he or she will have a good recovery [5]. Despite this knowledge, patients often arrive at a hospital too late to receive maximum treatment benefit from advanced stroke therapies; delay in hospital represents a major barrier to medical treatment [6-8]. The median time from symptom onset to a patient's hospital admission is between 3.5 and $14 \mathrm{~h}$, although it is difficult to directly compare studies with different designs [7-15]. As such, less than $5 \%$ of stroke patients are treated by thrombolysis, even in centers specialized for stroke [16].

Thrombolysis for ischemic stroke can only be performed after the possibility of a hemorrhage has been excluded by computed tomography (CT) imaging, and a CT scan without contrast is recommended in patients who have a suspected stroke within a 3-4.5 h time period $[17,18]$. Since not all hospitals are able to provide CT scans $24 \mathrm{~h}$ per day, important time is lost transporting patients to CT-capable centers [17]. The convergence of emergency medical services (EMS), telemedicine, and mobile technology, including transportable CT scanners, has presented a unique opportunity to advance patient stroke care in the prehospital field by circumventing delay to hyperacute stroke treatment with a mobile stroke unit (MSU) [19].

A MSU, also known as a stroke emergency mobile (STEMO) or mobile stroke treatment unit (MSTU), combines a specially trained team, conventional emergency equipment, telemedicine capabilities, a CT scanner, and diagnostic tools used to make an emergent decision for or against thrombolysis directly at the place where a patient is found (Fig. 1) [17]. This provides physicians the information and resources necessary to safely screen patients for IV tPA eligibility and initiate thrombolysis in the field, markedly curtailing symptom onset to treatment times by advancing acute stroke care in the prehospital field [17]. Hyperacute stroke workup at the scene can avoid transport delays, streamline procedures, and provide a highly specialized team ready for acute stroke diagnosis and treatment; implementation of these advances may lead to earlier stroke identification and shorten time to therapy $[17,19]$. In this review, we provide a look at the evolution of the MSU into its current status, as well as future directions, through historical and implementation information, economic cost, and published clinical outcome and time metrics. 

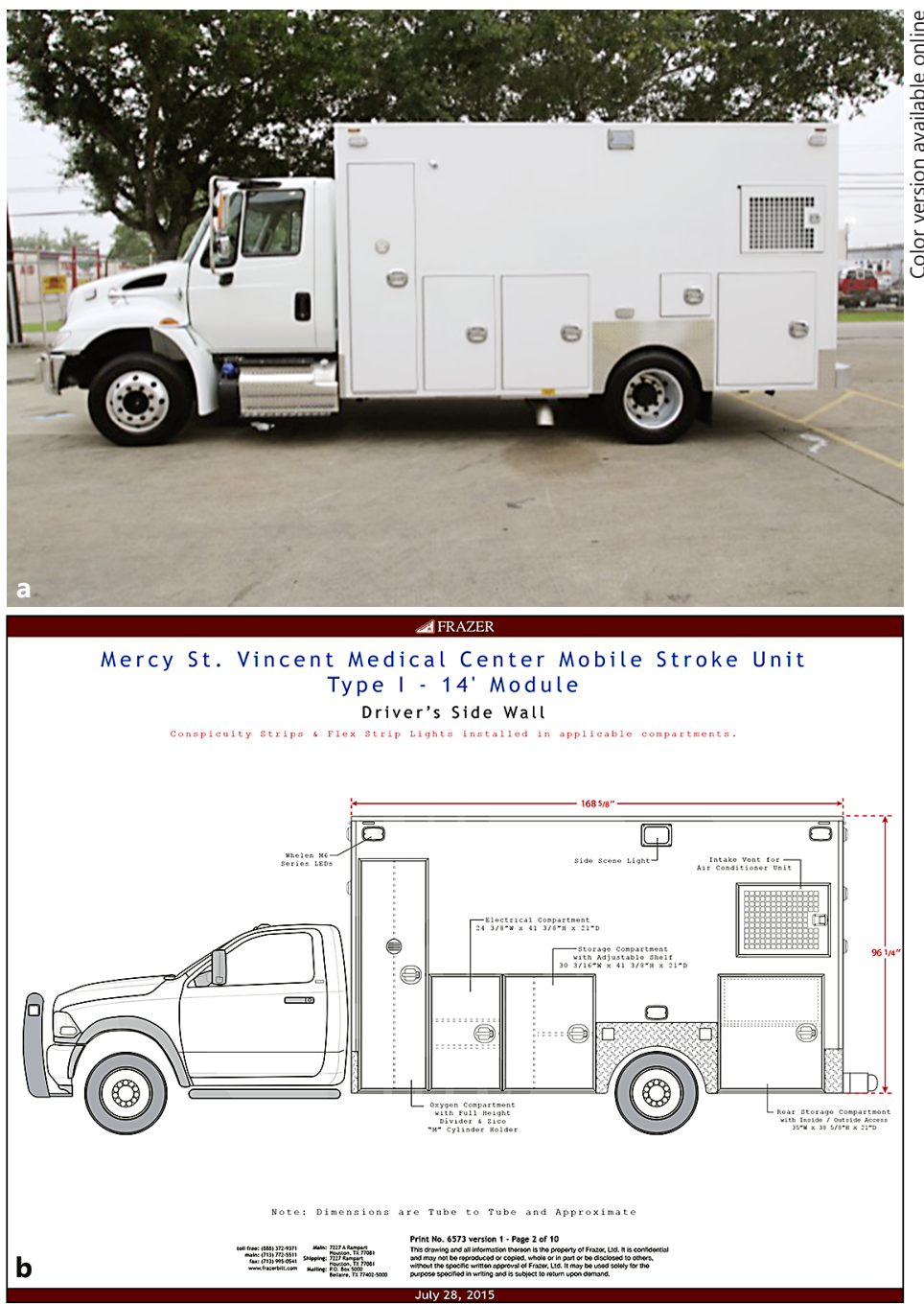

Fig. 1. a A mobile stroke unit ambulance built by Frazer. b Mercy Health Mobile Stroke Unit.

\section{Methods}

A literature search was conducted using PubMed and Google Scholar. A literature retrieval with assistance from Mercy Regional Library Services was also utilized. The key words used to search the stroke literature between 1990 and 2017 included "mobile stroke," "MSU," "mobile stroke unit," "telemedicine," "emergency medical services," "prehospital phase," "stroke management," and "thrombolysis." The references of identified articles were also reviewed for any MSU-related research. Internet search engines, such as Google, were also used to search for pages that might provide relevant references. Articles were selected on the basis of their relevance to the topic of MSUs and prehospital stroke management. Our search was restricted to reports in English. Thirty-eight papers were chosen for this review.

\section{Results}

\section{History of the MSU}

In 2003, Fassbender et al. [17] proposed the idea of a mobile unit for hyperacute stroke treatment to address the delay between stroke symptom onset, or last known well (LKW), and therapeutic intervention, to save important time lost by patient transfer to and within a 


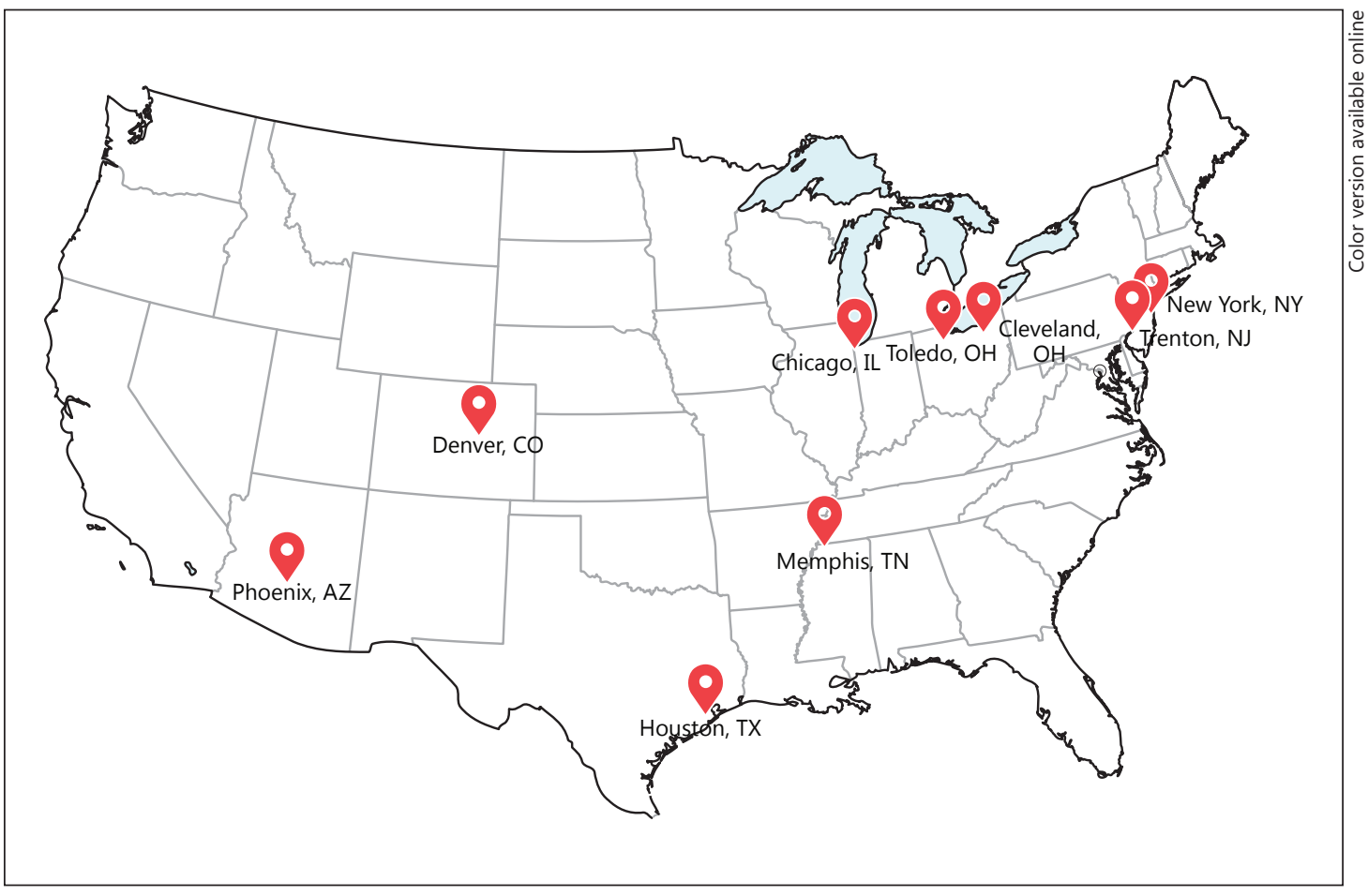

Fig. 2. Map of mobile stroke units launched by June 2017 in the United States.

hospital. Unlike a stationary stroke unit, the hypothesized MSU vehicle could carry diagnostic tools used to decide for or against thrombolysis at the site, in addition to conventional emergency equipment. At the time, this idea required unique technical innovations, all of which needed to remain within the normal limits of emergency vehicle dimensions, including a small, integrated CT scanner with an operation console and energy supply, a CT radiation shield, an optional laboratory unit, and a system to transmit CT information [17].

Beginning in 2009, a randomized clinical trial by the Saarland University Hospital in Homburg, Germany evaluated the feasibility of this prehospital healthcare delivery system [20]. The first MSU, or "stroke ambulance," was successfully founded in 2010 in Homburg, Germany after a year of preparation [21]. The specialized ambulance, in addition to its conventional equipment, was outfitted with an accumulator-driven, lead-shielded CT, a telemedicine system, and a point-of-care laboratory system [20]. These components, which are necessary for making therapeutic decisions, still comprise modern MSUs.

Guideline-adherent and etiology-specific treatments for ischemic and hemorrhagic strokes in the prehospital phase of stroke management were demonstrated by two MSU cases in Homburg [22]. These examples showed that MSUs are capable of more than expediting acute ischemic stroke treatment. They may also use telemedicine to contact hospital experts, manage physiological variables, improve hospital transport decision-making, and facilitate and expedite emergent care for other neurological emergencies [22].

The second MSU was launched in Berlin, Germany in July 2011 [23]. The Pre-Hospital Acute Neurological Therapy and Optimization of Medical Care in Stroke Patients (PHANTOM-S) study compared the MSU, or STEMO, to conventional care [23]. Study weeks were designated to STEMO service or routine care (control) [24]. The PHANTOM-S study concluded that using ambulance-based thrombolysis decreased time to treatment without increasing adverse events; however, more research is necessary to assess MSU effects on patient clinical outcomes [24]. 
With promising results from Homburg and Berlin, the first MSU in the United States went live in Houston, TX in May 2014 [22]. The Cleveland Clinic followed suit, launching their MSU in July 2014 [25]. The third MSU in the United States was launched in Denver, CO in January 2016. Similar to the MSUs in Germany, these were not operational $24 \mathrm{~h}$ a day, 7 days a week. The Mercy Health MSU in Toledo, OH was launched later in January 2016 as the fourth MSU in the country; it remains the only 24/7 MSU in the world. Other additional MSU locations in the United States include Memphis, TN (July 2016), New York, NY (October 2016), Chicago, IL (January 2017), Trenton, NJ (January 2017), and Phoenix, AZ (June 2017) (Fig. 2; Table 1). The number of MSUs worldwide continues to increase every year.

\section{Implementation}

Establishing a streamlined integration of MSUs into a conventional, prehospital EMS chain is vital. This requires cooperation from stakeholders in both the prehospital and in-hospital phase, including MSU staff, hospital administrators, EMS personnel, and the community. This multidisciplinary team is integral in seeking funding, purchasing, and building-out the physical MSU, as well as licensing, inspecting, equipping, insuring, and credentialing the vehicle before integrating it with local EMS [26].

MSU staff and local EMS also require training to conduct their roles on the rig, as they have not been previously exposed to CT imaging or the administration of thrombolytics in the field. Follow-up training and feedback from the numerous teams that arrive at the scene to evaluate and treat a patient is needed to improve patient outcomes and develop accountability with a feedback system.

Several MSUs were first launched with a pilot program period to test stakeholder roles and determine important research variables, including expected enrollment rate and patient demographics $[21,22,24]$. These test periods allowed new MSUs to identify potential problems, such as EMS integration or telemedicine connection, as well as areas of growth before resuming regular service.

\section{Personnel}

A functioning MSU requires substantial dedicated manpower. For example, the Houston MSU has required employment of a principal investigator, a program manager, and at least two vascular neurologists (VNs), in addition to the EMS personnel staffing the ambulance [22]. These include a critical care nurse, a CT technician, and an EMS provider or paramedic. A VN may also physically travel with the MSU or participate on scene using telemedicine technology. The BEST-MSU study in Houston is determining whether it is advantageous to have a VN on board instead of sole availability through telemedicine, as well the viability of cross-training MSU team members to complete multiple tasks, including cross-training a paramedic as a CT technician [26]. If possible, a future MSU team will include three individuals on board: a paramedic, an emergency medical technician, and a critical care nurse could carry out MSU tasks [26]. A complete list of on-board personnel for specific MSUs can be found in Table 1.

MSUs generally rely on dispatchers from a standard emergency medical system response to identify and alert the MSU of potential strokes. If an EMS team arrives first, the patient will be administered a prehospital scale and the MSU will be mobilized in the appropriate clinical circumstances. Upon arrival, the MSU team assumes care of the patient for further assessment and management, with a decision made regarding triage and drop-off destination.

At the emergency site, the MSU team is responsible for obtaining a patient history, a neurological and laboratory examination, a CT scan (if appropriate), and an evaluation with the remote $\mathrm{VN}$ via telemedicine. If eligible, thrombolysis is given onsite. 
Table 1. MSUs launched by June 2017

\begin{tabular}{|c|c|c|c|c|}
\hline Location & $\begin{array}{l}\text { Began } \\
\text { service }\end{array}$ & On-board personnel & Operating hours & Catchment area \\
\hline $\begin{array}{l}\text { Homburg, } \\
\text { Germany }\end{array}$ & $\begin{array}{l}\text { March } \\
2011\end{array}$ & UNK & UNK & $\begin{array}{l}20 \mathrm{~km} \text { around the university } \\
\text { hospital }\end{array}$ \\
\hline $\begin{array}{l}\text { Berlin, } \\
\text { Germany }\end{array}$ & $\begin{array}{l}\text { July } \\
2011\end{array}$ & $\begin{array}{l}\text { paramedic, stroke physician, } \\
\text { neuroradiologist }\end{array}$ & UNK & $\begin{array}{l}20 \mathrm{~km} \text { around the university } \\
\text { hospital }\end{array}$ \\
\hline $\begin{array}{l}\text { Fredrikstad, } \\
\text { Norway }\end{array}$ & $\begin{array}{l}\text { October } \\
2014\end{array}$ & $\begin{array}{l}\text { neurologist, paramedic, } \\
\text { radiology technician }\end{array}$ & $\begin{array}{l}\text { 07:00-11:00 daily, } \\
\text { Monday to Sunday, } \\
\text { randomized weeks }\end{array}$ & $\begin{array}{l}\text { defined by a } 75 \% \text { probability of } \\
\text { reaching the emergency sites } \\
\text { within } 16 \text { min from base, based } \\
\text { on calculations by the Berlin } \\
\text { Fire Department }\end{array}$ \\
\hline $\begin{array}{l}\text { Houston, } \\
\text { TX, USA }\end{array}$ & $\begin{array}{l}\text { May } \\
2014\end{array}$ & $\begin{array}{l}\mathrm{CT} \text { technician, } \mathrm{VN}, \mathrm{RN}, \\
\text { paramedic }\end{array}$ & $\begin{array}{l}\text { 08:00-18:00 daily, } \\
\text { Tuesday morning } \\
\text { to Monday evening, } \\
50 \% \text { weeks }\end{array}$ & 3 -mile radius \\
\hline $\begin{array}{l}\text { Cleveland, } \\
\text { OH, USA }\end{array}$ & $\begin{array}{l}\text { July } \\
2014\end{array}$ & CCN, EMT, paramedic, CT & 08:00-20:00 daily & UNK \\
\hline $\begin{array}{l}\text { Buenos Aires, } \\
\text { Argentina }\end{array}$ & $\begin{array}{l}\text { October } \\
2014\end{array}$ & UNK & UNK & UNK \\
\hline $\begin{array}{l}\text { Denver, } \\
\text { CO, USA }\end{array}$ & $\begin{array}{l}\text { January } \\
2016\end{array}$ & $\begin{array}{l}\text { neurologist }{ }^{\mathrm{a}}, \mathrm{CCN}, \\
\text { technician, paramedic, EMT }\end{array}$ & UNK & UNK \\
\hline $\begin{array}{l}\text { Toledo, } \\
\text { OH, USA }\end{array}$ & $\begin{array}{l}\text { January } \\
2016\end{array}$ & $\begin{array}{l}\mathrm{VN}^{\mathrm{a}}, \text { critical care transport } \\
\text { nurse, critical care transport } \\
\text { paramedic, CT technician }\end{array}$ & $24 / 7$ & $\begin{array}{l}\text { defined as a } 15 \text {-min drive time } \\
\text { radius, but fire departments } \\
\text { and EMS can also "special } \\
\text { request" the MSU }\end{array}$ \\
\hline $\begin{array}{l}\text { Memphis, } \\
\text { TN, USA }\end{array}$ & $\begin{array}{l}\text { July } \\
2016\end{array}$ & $\begin{array}{l}\text { stroke fellowship-trained } \\
\text { doctorally prepared nurses, } \\
\text { Advanced Neurovascular } \\
\text { Practitioner board certified }\end{array}$ & $\begin{array}{l}12 \text { h a day, } \\
1 \text { week on, } \\
1 \text { week off }\end{array}$ & $\begin{array}{l}\text { 10-mile radius but can be } \\
\text { dispatched within the entire } \\
\text { city metro area }\end{array}$ \\
\hline $\begin{array}{l}\text { New York, } \\
\text { NY, USA }\end{array}$ & $\begin{array}{l}\text { October } \\
2016\end{array}$ & $\begin{array}{l}\text { neurologist, } 2 \text { paramedics, } \\
\text { CT technician }\end{array}$ & UNK & $\begin{array}{l}\text { communities surrounding } \\
\text { NY-Presbyterian/Weill Cornell } \\
\text { Medical Center/Columbia } \\
\text { University Medical Center }\end{array}$ \\
\hline $\begin{array}{l}\text { Chicago, } \\
\text { IL, USA }\end{array}$ & $\begin{array}{l}\text { January } \\
2017\end{array}$ & UNK & UNK & $\begin{array}{l}\text { communities surrounding Rush } \\
\text { Oak Park Hospital that are part } \\
\text { of Illinois Region VII }\end{array}$ \\
\hline $\begin{array}{l}\text { Trenton, } \\
\text { NJ, USA }\end{array}$ & $\begin{array}{l}\text { January } \\
2017\end{array}$ & UNK & 07:00-23:00 daily & Mercer County area \\
\hline $\begin{array}{l}\text { Edmonton, } \\
\text { AB, Canada }\end{array}$ & $\begin{array}{l}\text { February } \\
2017\end{array}$ & $\begin{array}{l}\mathrm{VN}^{\mathrm{a}}, 2 \text { paramedics, } \mathrm{CT} \\
\text { technician }\end{array}$ & UNK & $\begin{array}{l}\text { communities surrounding } \\
\text { University of Alberta Hospital }\end{array}$ \\
\hline $\begin{array}{l}\text { Phoenix, } \\
\text { AZ, USA }\end{array}$ & $\begin{array}{l}\text { June } \\
2017\end{array}$ & VN and neurologists ${ }^{\mathrm{a}}$, EMT & UNK & $\begin{array}{l}\text { St. Joseph's Hospital and } \\
\text { Medical with 20-min response } \\
\text { radius }\end{array}$ \\
\hline
\end{tabular}

CCN, critical care nurse; CT, computed tomography; EMS, emergency medical services; EMT, emergency medical

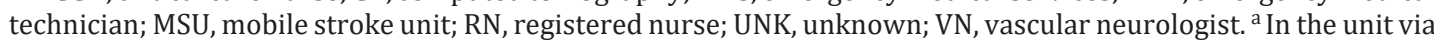
telemedicine technology. 


\section{Technology and Equipment}

The technology necessary to equip a MSU includes a CT scanner, a point-of-care laboratory system, and telemedicine capabilities for contact with hospital staff [20]. The point-ofcare laboratory system utilized in the Mercy Health MSU features the iStat machine. This is the standard system for point-of-care laboratories used in the emergency department and is licensed by Mercy Health-St. Vincent Medical Center. During a possible stroke case, a basic metabolic panel is completed. The panel includes serum sodium, potassium, chloride, ionized calcium, total $\mathrm{CO}_{2}$, glucose, blood urea nitrogen, creatinine, hematocrit, hemoglobin, and the anion gap. The Mercy Health MSU also has the ability to check prothrombin time/international normalized ratio using a CoaguChek machine, although this is usually only done on patients who are known to be on warfarin therapy.

The rising accuracy and reliability of telemedicine has made it an integral part of MSUs. For MSUs that do not have a VN or other specialized personnel on board, telemedicine can offer a way for real-time patient evaluation. Ebinger et al. [24] write that regions that lack enough neurologists may also use telemedicine as a way to provide expertise to the emergency physician or staff on board.

\section{Economics and Billing}

Establishing a MSU requires a large financial investment. Two available cost-effectiveness studies suggest that the financial expenditures incurred by MSUs are worthwhile in the long run $[27,28]$. Time and economic benefits have been shown to justify specialized ambulances up to an average travel times of $18 \mathrm{~min}$ in metropolitan areas [29]. MSU programs have also sought ways of increasing cost-effectiveness in the build-out phase. Parker et al. [22] describe how the Houston MSU used an ambulance design already in use by Houston EMS to help lower startup costs. An emphasis on lowered costs will improve cost-benefit ratios when appealing for MSU coverage by healthcare payers.

In the United States healthcare system, Medicaid and Medicare cover ambulance and other emergency services according to guidelines that define emergent situations. For example, Medicare part B covers ambulance services to the nearest appropriate facility specifically when other modes of transportation could further endanger the patient [30]. Medicaid follows much of the same standards, but will also cover nonemergent rides with a doctor's note [31]. As it is imperative to provide patients with prompt evaluation and treatment in suspected stroke scenarios, MSUs can potentially be covered and reimbursed according to a similar model. If MSUs were covered according to a low-cost model, more patient costs could be covered.

\section{Current Clinical Data and Outcomes}

MSUs have been developed to close the gap in time from LKW to treatment. The current state of evidence for prehospital stroke care from a MSU is largely determined by related quality measures, such as time to treatment from symptom onset, emergency site, or hospital door. Less evidence concerning improved functional outcomes in patients treated by MSUs exists at the present time.

The results of the first MSU randomized trial showed that prehospital management achieved a median symptom onset to therapy decision time of $56 \mathrm{~min}$ and a median symptom onset to treatment time of $72 \mathrm{~min}$ without impaired safety [21]. The number of patients who received therapy within the "golden hour" from LKW also increased significantly from 4\% (2 of 42 patients in the control group) to $57 \%$ (30 of 54 patients in the MSU group) [21]. The PHANTOM-S study, conducted in Berlin, showed that ambulance-based thrombolysis using a MSU resulted in decreased time to treatment and a ten-fold increase in the rate of "golden hour" thrombolysis versus conventional care [32]. The high rate of "golden hour" throm- 


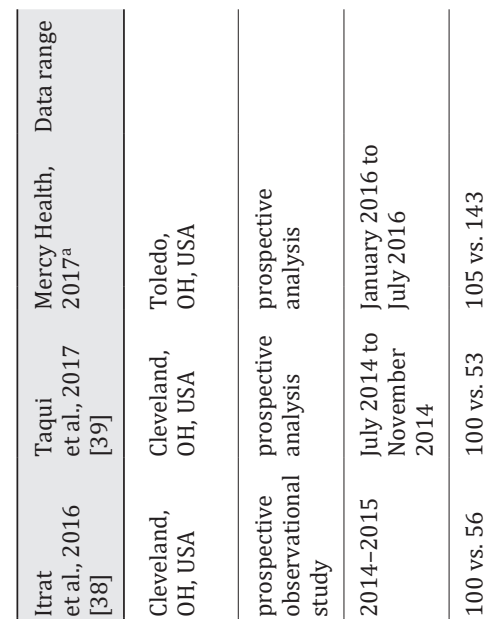

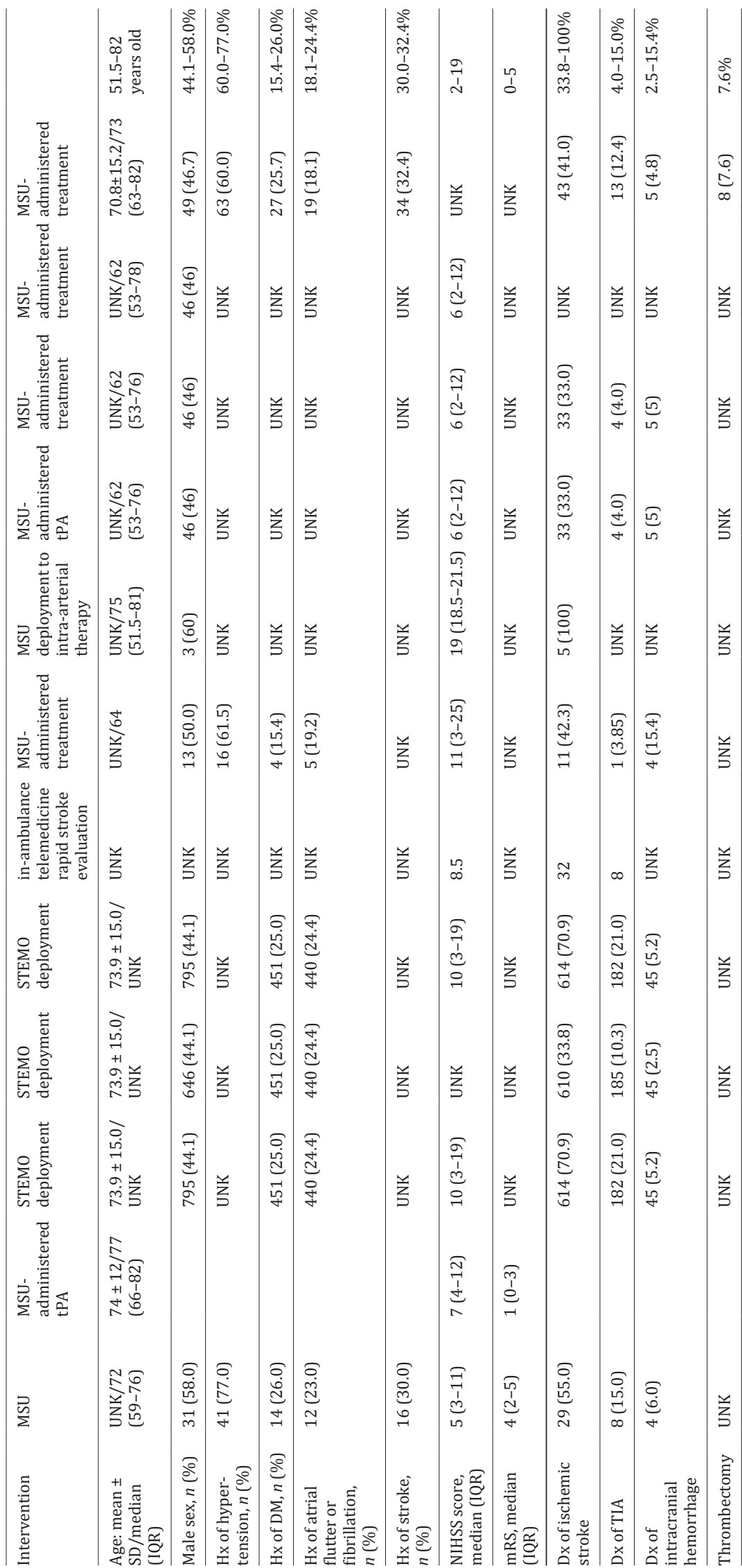

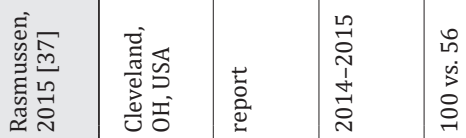

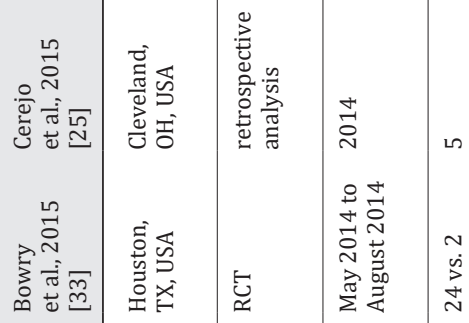

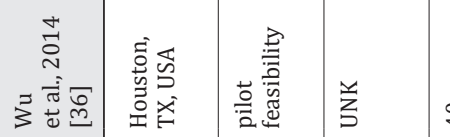

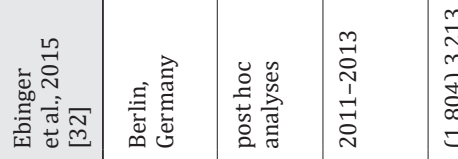

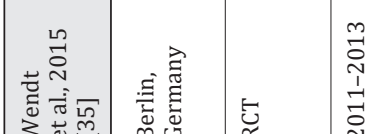

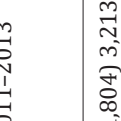

उच च

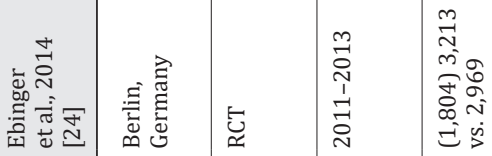

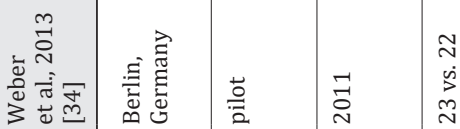

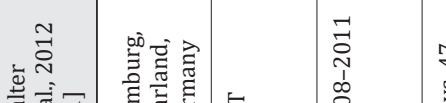

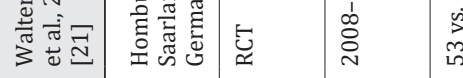

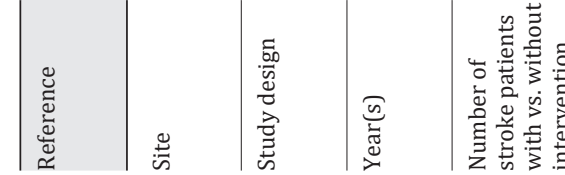




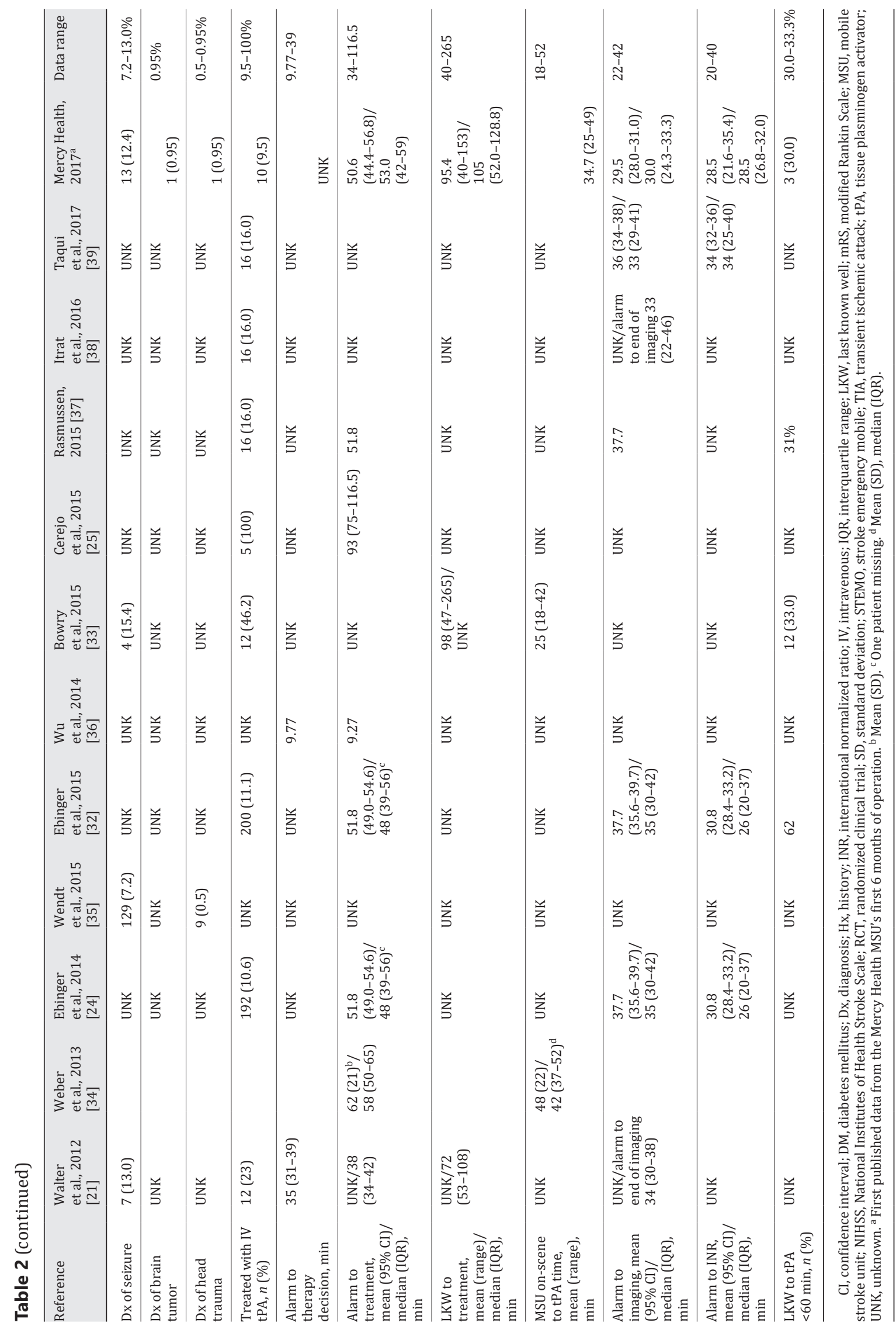




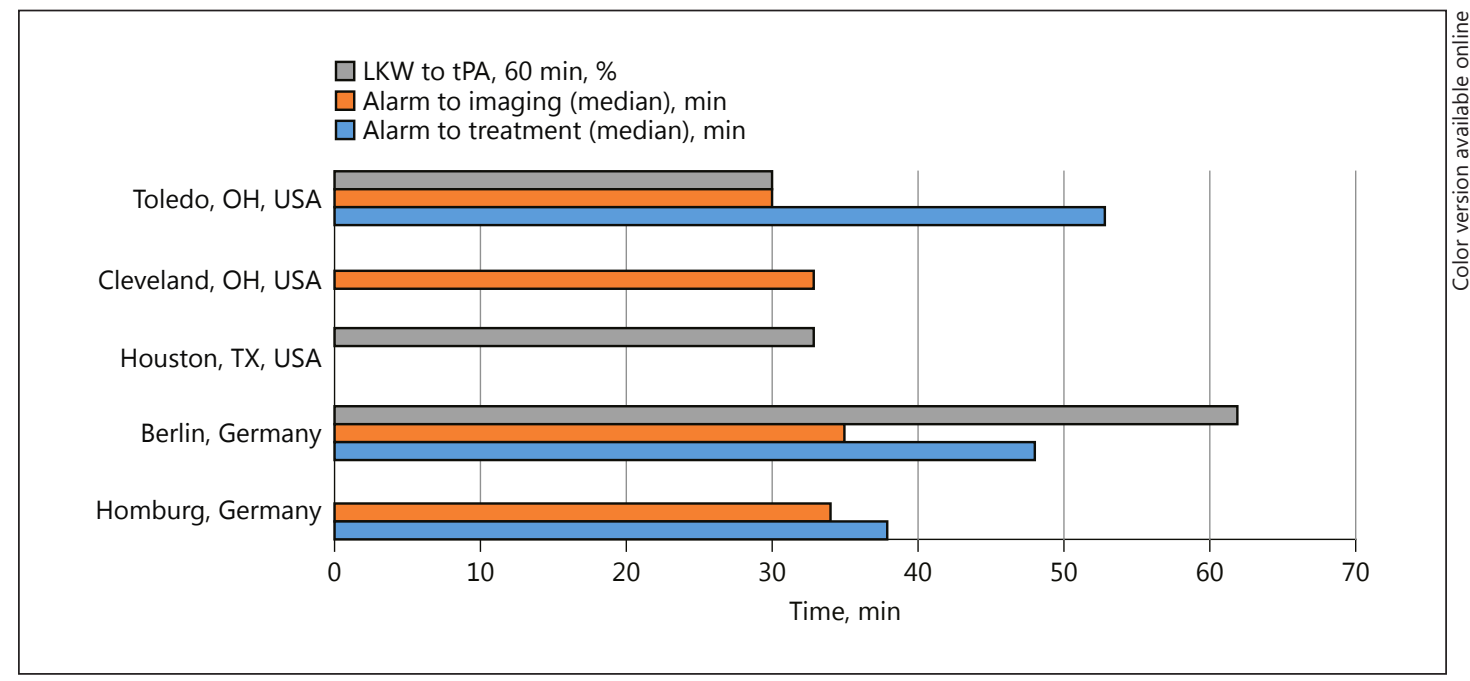

Fig. 3. Mobile stroke unit time metrics comparison. LKW, last known well; tPA, tissue plasminogen activator.

bolysis with MSU implementation demonstrated in Germany has also been shown to be reproducible in prehospital settings outside of Germany as well [33]. Published MSU clinical outcomes and data can be found in Table 2 and a time metrics comparison in Figure 3.

\section{Discussion}

\section{Feasibility of Implementation}

The funding and building of a MSU from first concept to implementation within 11 months in Houston attests to the feasibility of implementing MSUs around the world. Creative efforts taken to keep MSU costs down at startup, such as the implementation of ambulance designs already used by local EMS and collaboration with local stakeholders, can make project startup more feasible and affordable for all parties [10]. Further, the MSU team could also become smaller, and possibly more economically viable, through reducing personnel cost by crosstraining team members. In the future, a team could include three individuals on board: a paramedic, an emergency medical technician, and a critical care nurse; they could carry out patient care, conduct the CT scan, and interact with a remote VN via telemedicine [10]. Other areas of the United States healthcare system may require more attention to ease MSU implementation, including addressing the high cost of tPA [22]. There currently exists no Centers for Medicare \& Medicaid Services billing code to reimburse the Houston MSU for the cost of recombinant tPA given in the prehospital environment.

\section{Future Research}

The benefits of a MSU extend beyond the treatment of ischemic strokes with tPA to include hemorrhagic strokes and other acute neurological emergencies. As MSUs become more widespread, more research is necessary to provide further cost-benefit analysis. Additionally, further studies are needed to assess whether improved treatment times result in more favorable patient outcomes [32]. Future research may also determine definitively whether a MSU can optimize the identification and diagnosis of large vessel occlusions with higher sensitivity and specificity, as well as post-tPA interventional management. 


\section{Summary and Conclusions}

Initially hypothesized in 2003, the first MSUs came to fruition in Germany and were adopted worldwide in acute, prehospital stroke management. These specialized ambulances have made the diagnosis and treatment of many neurological emergencies, in addition to ischemic and hemorrhagic stroke, possible directly at the emergency site. As MSUs continue to collect data and improve their methods, shortened time metrics are expected, as well as an increase in the number of acute neurological patients who can benefit from rapid treatment and improved outcomes in the prehospital setting.

\section{Acknowledgments}

The authors would like to thank Dr. Ali Sultan-Qurraie for his assistance in editing the manuscript.

\section{Disclosure Statement}

The authors declare that the research was conducted in the absence of any commercial or financial relationships that could be construed as a potential conflict of interest.

\section{References}

1 Mozaffarian D, Benjamin EJ, Go AS, Arnett DK, Blaha MJ, Cushman M, de Ferranti S, Després JP, Fullerton HJ, Howard VJ, Huffman MD, Judd SE, Kissela BM, Lackland DT, Lichtman JH, Lisabeth LD, Liu S, Mackey RH, Matchar DB, McGuire DK, Mohler ER 3rd, Moy CS, Muntner P, Mussolino ME, Nasir K, Neumar RW, Nichol G, Palaniappan L, Pandey DK, Reeves MJ, Rodriguez CJ, Sorlie PD, Stein J, Towfighi A, Turan TN, Virani SS, Willey JZ, Woo D, Yeh RW, Turner MB; American Heart Association Statistics Committee and Stroke Statistics Subcommittee: Heart disease and stroke statistics - 2015 update: a report from the American Heart Association. Circulation 2015; 131:e29-e322.

2 Saver JL: Time is brain - quantified. Stroke 2006;37:263-266.

-3 Hacke W, Kaste M, Bluhmki E, Brozman M, Davalos A, Guidetti D, Larrue V, Lees KR, Medeghri Z, Machnig T, Schneider D, von Kummer R, Wahlgren N, Toni D; ECASS Investigators: Thrombolysis with alteplase 3 to 4.5 hours after acute ischemic stroke. N Engl J Med 2008;359:1317-1329.

-4 Del Zoppo GJ, Saver JL, Jauch EC, Adams HP Jr; on behalf of the American Heart Association Stroke Council: Expansion of the time window for treatment of acute ischemic stroke with intravenous tissue plasminogen activator: a science advisory from the American Heart Association/American Stroke Association. Stroke 2009;40: 2945-2948.

-5 Lees KR, Bluhmki E, von Kummer R, Brott TG, Toni D, Grotta JC, Albers GW, Kaste M, Marler JR, Hamilton SA, Tilley BC, Davis SM, Donnan GA, Hacke W; ECASS, ATLANTIS, NINDS and EPITHET rt-PA Study Group, Allen K, Mau J, Meier D, del Zoppo G, De Silva DA, Butcher KS, Parsons MW, Barber PA, Levi C, Bladin C, Byrnes G: Time to treatment with intravenous alteplase and outcome in stroke: an updated pooled analysis of ECASS, ATLANTIS, NINDS, and EPITHET trials. Lancet 2010;375:1695-1703.

6 Smith MA, Doliszny KM, Shahar E, McGovern PG, Arnett DK, Luepker RV: Delayed hospital arrival for acute stroke: the Minnesota Stroke Survey. Ann Intern Med 1998;129:190-196.

-7 Jorgensen HS, Nakayama H, Reith J, Raaschou HO, Olsen TS: Factors delaying hospital admission in acute stroke: the Copenhagen Stroke Study. Neurology 1996;47:383-387.

8 Wester P, Radberg J, Lundgren B, Peltonen M: Factors associated with delayed admission to hospital and in-hospital delays in acute stroke and TIA: a prospective, multicenter study. Seek-Medical-Attention-in-Time Study Group. Stroke 1999;30:40-48.

-9 Foulkes MA, Wolf PA, Price TR, Mohr JP, Hier DB: The Stroke Data Bank: design, methods, and baseline characteristics. Stroke 1988;19:547-554.

10 Asplund K, Carlberg B: Thrombolysis in stroke: timing of recanalization and its clinical consequences; in Hacke W, del Zoppo GJ, Hirschberg M (eds): Thrombolytic Therapy in Acute Ischemic Stroke. Berlin, Springer, 1991, pp 46-59.

11 Herderschee D, Limburg M, Hijdra A, Bollen A, Pluvier J, te Water W: Timing of hospital admission in a prospective series of stroke patients. Cerebrovasc Dis 1991;1:165-167.

12 Harper GD, Haigh RA, Potter JF, Castleden CM: Factors delaying hospital admission after stroke in Leicestershire. Stroke 1992;23:835-838.

13 Ferro JM, Melo TP, Oliveira V, Crespo M, Canhao P, Pinto AN: An analysis of the admission delay of acute stroke. Cerebrovasc Dis 1994;4:72-75. 


\section{Interventional Neurology}

$>14$

15 Fogelholm R, Murros K, Rissanen A, Ilmavirta M: Factors delaying hospital admission after acute stroke. Stroke 1996;27:398-400.

16 Easton DJ: Thrombolysis for stroke. Cerebrovasc Dis 1998;8:191-197.

17 Fassbender K, Walter S, Liu Y, Muehlhauser F, Ragoschke A, Kuehl S, Mielke O: "Mobile stroke unit” for hyperacute stroke treatment. Stroke 2003;34:e44.

18 Latchaw RE, Alerts MJ, Lev MH, Connors JJ, Harbaugh RE, Higashida RT: Recommendations for imaging of acute ischemic stroke. Stroke 2009;40:3646-3678.

19 Audebert HJ, Saver JL, Starkman S, Lees KR, Endres M: Prehospital stroke care: new prospects for treatment and clinical research. Neurology 2013;81:501-508.

20 Walter S, Kostopoulos P, Haass A, Helwig S, Keller I, Licina T, Schlechtriemen T, Roth C, Papanagiotou P, Zimmer A, Viera J, Körner H, Schmidt K, Romann MS, Alexandrou M, Yilmaz U, Grunwald I, Kubulus D, Lesmeister M, Ziegeler S, Pattar A, Golinski M, Liu Y, Volk T, Bertsch T, Reith W, Fassbender K: Bringing the hospital to the patient: first treatment of stroke patients at the emergency site. PLoS One 2010;5:e13758.

21 Walter S, Kostopoulos P, Haass A, Keller I, Lesmeister M, Schlechtriemen T, Roth C, Papanagiotou P, Grunwald I, Schumacher H, Helwig S, Viera J, Körner H, Alexandrou M, Yilmaz U, Ziegler K, Schmidt K, Dabew R, Kubulus D, Liu Y, Volk T, Kronfeld K, Ruckes C, Bertsch T, Reith W, Fassbender K: Diagnosis and treatment of patients with stroke in a mobile stroke unit versus in hospital: a randomised controlled trial. Lancet Neurol 2012;11:397-404. stroke unit in the United States. Stroke 2015;46:1384-1391.

23 Ebinger M, Rozanski M, Waldschmidt C, Weber J, Wendt M, Winter B, Kellner P, Baumann AM, Malzahn U, Heuschmann PU, Fiebach JB, Endres M, Audebert HJ; STEMO-Consortium: PHANTOM-S: the Pre-Hospital Acute Neurological Therapy and Optimization of Medical Care in Stroke Patients study. Int J Stroke 2012;7:348-353.

24 Ebinger M, Winter B, Wendt M, Weber JE, Waldschmidt C, Rozanski M, Kunz A, Koch P, Kellner PA, Gierhake D, Villringer K, Fiebach JB, Grittner U, Hartmann A, Mackert BM, Endres M, Audebert HJ; STEMO Consortium: Effect of the use of ambulance-based thrombolysis on time to thrombolysis in acute ischemic stroke: a randomized clinical trial. JAMA 2014;311:1622-1631.

-25 Cerejo R, John S, Buletko AB, Taqui A, Itrat A, Organek N, Cho SM, Sheikhi L, Uchino K, Briggs F, Reimer AP, Winners S, Toth G, Rasmussen P, Hussain MS: A mobile stroke treatment unit for field triage of patients for intraarterial revascularization therapy. J Neuroimaging 2015;6:940-945.

-26 Rajan SS, Baraniuk S, Parker S, Wu TC, Bowry R, Grotta JC: Implementing a mobile stroke unit program in the United States: why, how, and how much? JAMA Neurol 2015;72:229-234.

27 Gyrd-Hansen D, Olsen KR, Bollweg K, Kronborg C, Ebinger M, Audebert HJ: Cost-effectiveness estimate of preshospital thrombolysis - results of the PHANTOM-S study. Neurology 2015;84:1090-1097.

-28 Dietrich M, Silke W, Ragoschke-Schumm A, Helwig S, Levine S, Balucani C, Lesmeister M, Haass A, Liu Y, Lossius $\mathrm{HM}$, Fassbender K: Is prehospital treatment of acute stroke too expensive? An economic evaluation based on the first trial. Cerebrovasc Dis 2014;38:457-463.

29 Koch P, Kunz A, Ebinger M, Geisler F, Rozanski M, Waldschmidt C, Weber JE, Wendt M, Winter B, Zieschang K, Bollweg K, Kaczmarek S, Endres M, Audebert HJ: Influence of distance to scene on time to thrombolysis in a specialized stroke ambulance. Stroke 2016;47:2136-2140.

30 United States Center of Medicare and Medicaid Services. Ambulance services. ND.

31 United States Department of Health and Human Services. Does Medicaid cover ambulance services? ND. Ebinger M, Kunz A, Wendt M, Rozanski M, Winter B, Waldschmidt C, Weber J, Villringer K, Fiebach JB, Audebert HJ: Effects of golden hour thrombolysis: a Prehospital Acute Neurological Treatment and Optimization of Medical Care in Stroke (PHANTOM-S) substudy. JAMA Neurol 2015;72:25-30.

33 Bowry R, Parker S, Rajan SS, Yamal JM, Wu TC, Richardson L, Noser E, Persse D, Jackson K, Grotta JC: Benefits of stroke treatment using a mobile stroke unit compared with standard management: the BEST-MSU study run-in phase. Stroke 2015;46:3370-3374.

-34 Weber JE, Ebinger M, Rozanski M, Waldschmidt C, Wendt M, Winter B, Kellner P, Baumann A, Fiebach JB, Villringer K, Kaczmarek S, Endres M, Audebert HJ; STEMO-Consortium: Prehospital thrombolysis in acute stroke: results of the PHANTOM-S pilot study. Neurology 2013;80:163-168.

-35 Wendt M, Ebinger M, Kunz, A, Rozanski M, Waldschmidt C, Weber JE, Winter B, Koch PM, Freitas E, Reich J, Schlemmer D, Audebert HJ: Improved prehospital triage of patients with stroke in a specialized stroke ambulance: results of the Pre-Hospital Acute Neurological Therapy and Optimization of Medical Care in Stroke study. Stroke 2015;46:740-745.

-36 Wu TC, Nguyen C, Ankrom C, Yang J, Persse D, Vahidy F, Grotta JC, Savitz SI: Prehospital utility of rapid stroke evaluation using in-ambulance telemedicine: a pilot feasibility study. Stroke 2014;45:2342-2347.

37 Rasmussen P: Stroke management and the impact of mobile stroke treatment units. Cleve Clin J Med 2015;82(12 suppl 2):S17-S21.

38 Itrat A, Taqui A, Cerejo R, Briggs F, Cho SM, Organic N, Reimer A, Winner S, Rasmussen P, Hussain MS, Uchino K: Telemedicine in prehospital stroke evaluation and thrombolysis: taking stroke treatment to the doorstep. JAMA Neurol 2016;73:162-168.

-39 Taqui A, Cerejo R, Itrat A, Briggs FB, Reimer AP, Winners S, Organek N, Buletko AB, Sheikhi L, Cho SM, Buttrick M, Donohue MM, Khawaja Z, Wisco D, Frontera JA, Russman AN, Hustey FM, Kralovic DM, Rasmussen P, Uchino K, Hussain MS; Cleveland Pre-Hospital Acute Stroke Treatment (PHAST) Group: Reduction in time to treatment in prehospital telemedicine evaluation and thrombolysis. Neurology 2017;88:1305-1312. 